\title{
Persepsi perawat terhadap upaya pelayanan prima di rumah sakit
}

\author{
Eri Murni Asih ${ }^{1 *}$, Dessy Hermawan², Teguh Pribadi²
}

${ }^{1}$ RSUD dr.H.Bob Bazar,SKM Kabupaten Lampung Selatan. *Email Murni.gawoh@gmail.com

2Program Studi IImu Keperawatan Universitas Malahayati.

\section{Abstract \\ Nurses' perceptions of excellent health care services}

Background: As the spearhead of services to patients and their families at the hospital, nurses have a major influence on determining the quality of services, because the frequency of gathering among nurses, patient and patients family considere the most often. Therefore, a paradigm and mental attitude that is service-oriented are needed, as well as adequate knowledge and skills in carrying out excellent service.

Purpose: To describe nurses' perceptions of excellent health care services.

Method: An analytical with cross-sectional approach with the number of samples in this study was 53 responden taken by cluster random sampling. teh populations were all staff nurses at Dr. H. Bob Bazar, SKM General Hospital. South Lampung. Data collected through questionnaires and analyzed using univariate analysis, bivariate analysis, and multivariate with SPSS for Windows V. 22.

Results: Shows a relationship between perceived susceptibility with excellent service effort $(0.021<0.05)$, the relationship between perceived severity and excellent service effort ( $p$-value $0.001<0.05$ ), the relationship between perceived benefit of action and excellent service effort ( $p$-value $0.003<0.05$ ), the relationship between perceived barrier to action with excellent service efforts at Dr. H. Bob Bazar, General Hospital South Lampung ( $p$-value $0.007<0.05$ ), the perceived benefit of action variable is the most dominant variable affecting the prime service effort variable with the Exp value $(B)=46,512$.

Conclusion: A significant relationship between nurses perceived susceptibility, perceived severity, perceived benefit of action, and perceived of barriers from the action excellent service at Dr. H. Bob Bazar, SKM General Hospital South Lampung. The results of this study also found that there was a significant on simultaneous effect of all independent variables on the effort of excellent service.

\section{Keywords: Nurses' perceptions; Excellent health care services; Hospital}

Pendahuluan: Sebagai ujung tombak pelayanan terhadap pasien dan keluarganya di Rumah Sakit, perawat memiliki pengaruh besar untuk menentukan kualitas pelayanan, karena kuantitas frekuensi pertemuan perawat dengan pasien dinilai paling sering terjadi. Oleh karena itu, diperlukan paradigma dan sikap mental yang berorientasi melayani, serta pengetahuan dan keterampilan yang memadai dalam melaksanakan pelayanan yang prima.

Tujuan: Untuk mengetahui Pengaruh Persepsi Perawat Terhadap Upaya Pelayanan Prima RSUD dr.H. Bob Bazar, SKM Kabupaten Lampung Selatan.

Metode: Penelitian analitik dengan pendekatan cross sectional dengan jumlah sampel sebanyak 53 responden, diambi Isecara clusster random sampling menggunaan rumus slovin. Populasinya seluruh perawat yang bekerja di RSUD dr.H. Bob Bazar, SKM Kabupaten Lampung Selatan. Pengumpulan data melalui kuesioner dan data hasil penelitian dianalisis menggunakan analisis univariat, analisis bivariat, dan multivariat dengan program SPSS for Windows V. 22.

Hasil: Menunjukkan hubungan perceived susceptibility dengan upaya pelayanan prima $(0,021<0,05)$, hubungan antara (perceived severity dengan upaya pelayanan prima ( $p$-value $0,001<0,05$ ), hubungan antara perceived benefit of action dengan upaya pelayanan prima ( $p$-value $0,003<0,05$ ), hubungan antara perceived barrier to action dengan upaya pelayanan prima ( $p$-value $0,007<0,05$ ), variabel perceived benefit of action merupakan variabel yang paling dominan mempengaruhi variabel upaya pelayanan prima dengan nilai $\operatorname{Exp}(B)=46,512$.

Simpulan: Terdapat hubungan yang signifikan antara persepsi perawat tentang kerentanan/kemungkinan terkena suatu penyakit, persepsi perawat keparahan penyakit, persepsi perawat tentang manfaat dari tindakan, 
dan persepsi perawat tentang hambatan dari tindakan terhadap upaya pelayanan prima di Rumah Sakit Umum Dr. H. Bob Bazar, SKM Lampung. Terdapat pengaruh bersama secara signifikan seluruh variabel bebas penelitian terhadap upaya pelayanan prima.

\section{Kata kunci: Persepsi; Perawat; Upaya; Pelayanan prima; Rumah sakit}

\section{PENDAHULUAN}

Suatu pelayanan dikatakan baik oleh pasien, ditentukan oleh kenyataan apakah jasa yang diberikan tentang pelayanan yang diterima memuaskan atau mengecewakan, juga termasuk lamanya waktu pelayanan (Nursalam, 2014). Upaya Pelayanan Prima di Rumah Sakit adalah usaha memberikan pelayanan terbaik oleh karyawan rumah sakit untuk memenuhi atau bahkan melampaui harapan pengguna jasa rumah sakit (Purwoastuti \& Walyani 2015). Sumberdaya yang paling banyak menyumbang sebagai pendukung pelayanan prima dan kepuasan kepada pasien di Rumah Sakit, salah satunya adalah perawat. Dalam memberikan pelayanan keperawatan peranan perawat sangat penting sabagai salah satu alat ukur kualitas pelayanan kesehatan di suatu instansi rumah sakit (Subaris, 2016; Kementerian Kesehatan Republik Indonesia, 2009).

Kinerja perawat bukan saja dinilai dari kesedian tenaga keperawatan untuk melakukan tindakan tetapi lebih dari itu kinerja perawat harus memperhatikan kesediaan untuk melakukan tindakan dan motivasi karena itu merupakan suatu kewajiban sebagai tenaga kesehatan (Bakri, 2017; Hadjam, 2015; Lembaran Negara Republik Indonesia, 2014).

Penelitian sebelumnya tentang Proses Pelayanan Prima menyimpulkan bahwa rumah sakit harus memiliki sumber daya manusia yang berkualitas agar dapat bersaing dengan rumah sakit lain. Salah satu aspeknya adalah kemauan dan kemampuan dalam memberikan pelayanan yang prima, oleh karena itu, diperlukan paradigma dan sikap mental yang berorientasi melayani, serta pengetahuan dan keterampilan yang memadai dalam melaksanakan pelayanan yang prima (Agustin, 2017; Kementerian Kesehatan Republik Indonesia, 2019).

Pada Konfrensi International Mutu Pelayanan Kesehatan ISQUA di Tokyo 17-19 Oktober 2016, perwakilan negara Amerika, Australia dan Jepang menegaskan bahwa pada saat ini banyak negara di dunia sedang berusaha mewujudkan universal health coverage (UHC), sebagai salah satu target dari Sustainable Development Goal for health (SDG's), namun upaya untuk mengukur mutu pelayanan kesehatan dalam UHC masih kurang memadai, baru $30-50 \%$ pasien yang menerima pelayanan yang seharusnya didapatkan, untuk itu diperlukan "building in quality from the start", dimana sistem mutu seharusnya sudah dibangun sejak awal dalam UHC, jika tidak maka UHC hanya akan memberikan janji "kosong". Sistem mutu bukan sebagai pelengkap tapi justru menjadi dasar dalam pengembangan sistem pelayanan kesehatan. Untuk dapat mengukur mutu dalam UHC diperlukan mekanisme rutin untuk memonitor UHC termasuk mutu pelayanan kesehatan yang diberikan, untuk mengembangkan indikator mutu yang dapat digunakan sebagai perbandingan antar negara (Djasri, 2016; Stanhope, Faan, Lancaster, \& Faan, 2018).

Fenomena yang sering terjadi di beberapa rumah sakit, terutama berkaitan dengan pelayanan dimana kesenjangan antara kualitas pelayanan perawat ideal dengan perawat aktual menunjukkan hasil bahwa sikap perawat terhadap pencegahan infeksi nasokomial berhubungan erat dengan health belife model, jika perawat mampu menilai sejauh mana penyakit akan memberikan efek negatif pada orang lain baik perawat maupun pasien lainnya maka perawat akan memberikan pelayanan dengan sistem kewaspadaan universal dengan penggunaan alat perlindungan diri secara baik dan benar untuk menghindari penularan antar pasien (Nurseha, 2017; Husna, 2014; Kurniawan, Ibrahim, \& Suwignyo, 2011; Kuntoro, \& Istiono, 2017).

Hasil survei yang telah dilaksanakan oleh RSUD dr. Bob Bazar, SKM Kabupaten Lampung Selatan pada bulan April tahun 2018 tentang kepuasan pelanggan menunjukkan bahwa dari 100 orang responden yang terdiri dari pasien rawat jalan sebesar $70 \%$ mengeluhkan masih lambannya pelayanan dan antrian menunggu pelayanan oleh dokter spesialis, 30\% menyatakan kurangnya informasi baik dari petugas maupun banner petunjuk sehingga pasien harus bolak balik untuk menerima pelayanan dari satu loket keloket lainnya, 60\% responden menyatakan kurangnya

Eri Murni Asih"*, Dessy Hermawan ${ }^{2}$, Teguh Pribadi ${ }^{2}$

'RSUD dr.H.Bob Bazar,SKM Kabupaten Lampung Selatan. *Email Murni.gawoh@gmail.com

${ }^{2}$ Program Studi llmu Keperawatan Universitas Malahayati. 
informasi atau penjelasan yang diberikan oleh petugas baik perawat maupun bidan pada poli rawat jalan, dan $20 \%$ mengatakan cukup puas dengan pelayanan yang diberikan. Sehingga secara keseluruhan kepuasan pelanggan dalam menerima pelayanan dengan hasil sebesar $45 \%$ menunjukkan bahwa upaya pelayanan prima yang diberikan masih kurang maksimal.

Mutu pelayanan kesehatan tidak lepas dari rasa puas klien pasien terhadap pelayanan kesehatan yang diterima. Apabila pelayanan yang diberikan sesuai dengan harapan/keinginan klien/ pasien maka akan menimbulkan kepuasan pelanggan, namun sebaliknya apabila pelayanan yang diberikan tidak sesuai dengan harapan/keinginan pelanggan maka akan menimbulkan ketidakpuasan pelanggan atau keluhan pelanggan. Dalam hal ini, peneliti menggunakan Health Belief Model (HBM) yang dikembangkan para peneliti- peneliti pada pusat layanan kesehatan Amerika Serikat sejak tahun 1950, HBM telah menjadi model penjelasan yang utama untuk mengungkap perbedaan yang ada dalam perilaku kesehatan preventif sekaligus perbedaan dalam penggunaan pelayanan kesehatan preventif (Hayden, 2017; Setiyaningsih, Tamtomo, \& Suryani, 2016; Merita, 2016; Zrymiak, 2017).

\section{METODE PENELITIAN}

Penelitian analitik dengan pendekatan cross sectional dengan jumlah sampel sebanyak 53 responden dari dari total populasi yang diambil secara clusster random sampling menggunaan rumus slovin. Penelitian dilaksanakan pada bulan Februari tahun 2019 di RSUD Dr. Bob Bazar, SKM Kabupaten Lampung Selatan Tahun 2019. Variabel penelitian ini terdiri dari dua variabel, variabel bebasnya persepsi perawat tentang perceived susceptibility, perceived severity, perceived benefits dan perceifed barriers, sedangkan variabel terikatnya upaya pelayanan prima. Metode pengumpulan data melalui kuesioner dan data hasil penelitian dianalisis menggunakan program SPSS for Windows V. 22.

Analisis univariat dilakukan untuk melihat distribusi frekuensi variabel dependen dan variabel independen yang terdiri dari data perawat meliputi: tanggal lahir, jenis kelamin, pendidikan, pengalaman kerja, persepsi perawat tentang perceived susceptibility, perceived severity, perceived benefits dan perceifed barriers,serta upaya pelayanan prima. Analisis bivariat dilakukan untuk mengetahui hubungan antara variabel independen dengan variabel dependen, yaitu hubungan antara persepsi perawat dengan upaya pelayanan prima. Uji statistik yang digunakan adalah uji Chi Square. Analisis Multivariat digunakan untuk mencari pengaruh masing-masing variabel bebas secara bersama-sama terhadap variabel terikat serta mencari manakah variabel bebas yang paling berpengaruh terhadap variabel terikat dengan uji analisis regresi logistik. 
HASIL

Tabel 1. Karakteristik Responden $\mathrm{N}=53$

\begin{tabular}{lcc}
\hline Variabel & Frekuensi (f) & Persentase (\%) \\
\hline Usia & & \\
$20-30$ & 12 & 22.64 \\
$30-40$ & 29 & 54.72 \\
$40-50$ & 9 & 16.98 \\
$>50$ & 3 & 5.66 \\
Jenis Kelamin & & \\
Pria & 15 & 28.30 \\
Wanita & 38 & 71.70 \\
& & \\
Jenjang Pendidikan & & \\
SPK & 2 & 3.78 \\
D III & 36 & 67.92 \\
S1 Keperawatan + Ners & 15 & 28.30 \\
& & \\
Pengalaman Kerja & & 11.33 \\
$<1$ tahun & 6 & 9.43 \\
$1-5$ tahun & 5 & 20.75 \\
$5-10$ tahun & 11 & 47.17 \\
$10-15$ tahun & 3 & 5.66 \\
$15-20$ tahun & 3 & 5.66 \\
$>20$ tahun & & \\
\hline
\end{tabular}

Berdasarkan data pada tabel 1 dapat diperoleh gambaran bahwa berdasarkan usia sebagian besar antara $30-40$ tahun sebanyak 29 responden $(54.72 \%)$, berjenis kelamin wanita sebanyak 30 responden $(71.70 \%)$, memiliki jenjang pendidikan DIII (Diploma III). 36 responden (67.92\%), dan memiliki pengalaman kerja $10-15$ tahun, yaitu sejumlah 25 responden (47.17\%). 
Tabel 2. Distribusi Persepsi Responden

\begin{tabular}{|c|c|c|c|c|c|c|c|c|}
\hline \multirow[t]{2}{*}{ Ruang } & \multicolumn{2}{|c|}{$\begin{array}{l}\text { Kemungkinan } \\
\text { Tertular Suatu } \\
\text { Penyakit Dari } \\
\text { Pelanggan/Pasien } \\
\text { (Perceived } \\
\text { Susceptibility) } \\
\end{array}$} & \multicolumn{2}{|c|}{$\begin{array}{l}\text { Keparahan } \\
\text { Penyakit } \\
\text { (Perceived } \\
\text { Severity) }\end{array}$} & \multicolumn{2}{|c|}{$\begin{array}{l}\text { Manfaat Dari } \\
\text { Tindakan (Perceived } \\
\text { Benefit of Action) }\end{array}$} & \multicolumn{2}{|c|}{$\begin{array}{l}\text { Hambatan Dari } \\
\text { Tindakan } \\
\text { (Perceived Barrier } \\
\text { to Action) }\end{array}$} \\
\hline & Rerata & Kategori & Rerata & Kategori & Rerata & Kategori & Rerata & Kategori \\
\hline $\begin{array}{l}\text { Ruang } \\
\text { Rawat Jalan }\end{array}$ & 3.00 & Positif & 3.20 & Positif & 3.34 & Positif & 2.85 & Positif \\
\hline $\begin{array}{l}\text { Ruang } \\
\text { Rawat Inap } \\
\text { Dewasa }\end{array}$ & 2.90 & Positif & 2.97 & Positif & 3.08 & Positif & 3.05 & Positif \\
\hline $\begin{array}{l}\text { Unit Gawat } \\
\text { Darurat }\end{array}$ & 3.00 & Positif & 2.86 & Positif & 2.95 & Positif & 3.11 & Positif \\
\hline $\begin{array}{l}\text { Ruang } \\
\text { Operasi } \\
\text { (Bedah) }\end{array}$ & 2.50 & Negatif & 3.00 & Positif & 3.25 & Positif & 3.25 & Positif \\
\hline Ruang Anak & 2.75 & Positif & 2.50 & Positif & 3.04 & Positif & 2.88 & Positif \\
\hline
\end{tabular}

Berdasarkan tabel 2 diketahui bahwa terdapat perbedaan persepsi perawat tentang kemungkinan tertular suatu penyakit dari pasien (Perceived susceptibility), di mana perawat pada ruang rawat jalan, ruang rawat inap dewasa, unit gawat darurat, dan ruang anak memiliki persepsi positif terhadap kemungkinan tertular suatu penyakit dari pasien (Perceived susceptibility), yaitu dengan rentang skor $>2.50$ sementara perawat pada ruang operasi (bedah), memiliki persepsi negatif dengan rerata skor 2.50 .

Persepsi responden memiliki persepsi positif tentang Keparahan Penyakit (Perceived Severity), manfaat dari tindakan (perceived benefit of action), dan hambatan dari tindakan (perceived barrier to action) terjadi di semua ruangan dengan persepsi mereka berada pada rerata $>2.50$.

Tabel 3. Persepsi Perawat Terhadap Upaya Pelayanan Prima

\begin{tabular}{lcc}
\hline $\begin{array}{l}\text { Aspek-Aspek Upaya } \\
\text { Pelayanan Prima }\end{array}$ & Rerata Skor & Keterangan \\
\hline Aspek Penampilan Fisik & 3.19 & Melakukan \\
$\begin{array}{l}\text { Aspek Kemampuan } \\
\text { Pelayanan Yang Akurat }\end{array}$ & 3.09 & Melakukan \\
Aspek Daya Tanggap & 2.83 & Melakukan \\
Aspek Jaminan & 3.03 & Melakukan \\
Aspek Empati & 2.81 & Melakukan \\
\hline
\end{tabular}

Berdasarkan data tabel 3. dapat disimpulkan bahwa perawat telah melakukan upaya pelayanan prima disemua aspek yang terkait dengan aspek rerata skor tertinggi pada aspek penampilan fisik sebesar 3.19 
Tabel 4. Persepsi Perawat Dengan Upaya Pelayanan

\begin{tabular}{|c|c|c|c|c|c|c|c|c|}
\hline \multicolumn{9}{|c|}{ Upaya Pelayanan Prima } \\
\hline \multirow[t]{2}{*}{ Persepsi Perawat } & \multicolumn{2}{|c|}{$\begin{array}{l}\text { Tidak } \\
\text { Melakukan }\end{array}$} & \multicolumn{2}{|c|}{ Melakukan } & \multicolumn{2}{|c|}{ Total } & \multirow[t]{2}{*}{ p-value } & \multirow[t]{2}{*}{ OR (Cl 95\%) } \\
\hline & $\mathrm{n}$ & $\%$ & $\mathrm{n}$ & $\%$ & $\mathbf{N}$ & $\%$ & & \\
\hline \multicolumn{9}{|l|}{$\begin{array}{l}\text { Kerentanan (Perceived } \\
\text { Susceptibility) }\end{array}$} \\
\hline Negatif & 10 & 18.9 & 8 & 15.0 & 18 & 34.1 & .038 & 4,22 \\
\hline Positif & 8 & 15.0 & 27 & 50.9 & 35 & 65.9 & & $(1,3-14,3)$ \\
\hline \multicolumn{9}{|l|}{$\begin{array}{l}\text { Keparahan Penyakit } \\
\text { (Perceived Severity) }\end{array}$} \\
\hline Negatif & 11 & 20.7 & 4 & 7.5 & 15 & 28.2 & .001 & 12,18 \\
\hline Positif & 7 & 13.4 & 31 & 58.4 & 38 & 71.8 & & $(2,9-48,7)$ \\
\hline \multicolumn{9}{|l|}{$\begin{array}{l}\text { Manfaat Dari Tindakan } \\
\text { (Perceived Benefit of } \\
\text { Action) }\end{array}$} \\
\hline Negatif & 8 & 15.0 & 2 & 3.8 & 10 & 18.8 & .002 & 13,2 \\
\hline Positif & 10 & 18.9 & 33 & 62.3 & 43 & 81.2 & & $(2,4-72,5)$ \\
\hline \multicolumn{9}{|l|}{$\begin{array}{l}\text { Hambatan dari } \\
\text { Tindakan (Perceived } \\
\text { Barrier to Action) }\end{array}$} \\
\hline Negatif & 7 & 13.2 & 2 & 3.8 & 9 & 17 & .008 & 10,5 \\
\hline Positif & 11 & 20.7 & 33 & 62.3 & 44 & 83 & & $(1,9-58,30)$ \\
\hline
\end{tabular}

Berdasarkan data pada tabel 4. terlihat bahwa paling banyak responden berpersepsi positif perawat tentang kerentanan (Perceived Susceptibility) berhubungan upaya pelayanan prima yang dilakukan perawat yaitu 27 responden ( $50.9 \%)$. Hasil uji chi square didapatkan nilai $p$ value 0.038 , artinya lebih kecil dibandingkan dengan nilai alpha $(0,001<0,05)$. OR diperoleh nilai $4,22(\mathrm{Cl} 95 \%$ 1.3-14.3), artinya persepsi positif perawat tentang kerentanan (Perceived Susceptibility) memengaruhi mereka 4.25 kali lebih besar untuk melakukan upaya pelayanan prima.

Persepsi perawat tentang tentang keparahan penyakit (perceived severity) berhubungan dengan upaya pelayanan prima dimana persepsi positif perawat menyebabkan perawat melakukan upaya pelayanan prima sebanyak 31 responden (58.4\%). Hasil uji chi square didapatkan nilai $p$ value 0.001 . OR diperoleh nilai 12.18 (Cl 95\% 2.9-48.7), artinya persepsi positif perawat tentang keparahan penyakit (perceived severity) mendorong mereka 12.18 kali lebih besar untuk melakukan upaya pelayanan prima.

Persepsi perawat tentang tentang manfaat dari tindakan (perceived benefit of action) berhubungan dengan upaya pelayanan prima dimana persepsi positif perawat menyebabkan perawat melakukan upaya pelayanan prima sebanyak 33 responden (62.3\%). Hasil uji chi square didapatkan nilai p value 0.002 . Sedangkan hasil uji OR diperoleh nilai 13.2 (Cl 95\% 2.4-72.5), artinya persepsi positif perawat tentang manfaat dari tindakan (perceived benefit of action) mendorong mereka 13.2 kali lebih besar untuk melakukan upaya pelayanan prima.

Persepsi perawat tentang tentang hambatan dari tindakan (perceived barrier to action) berhubungan dengan upaya pelayanan prima dimana persepsi positif perawat menyebabkan perawat melakukan upaya pelayanan prima sebanyak 33 responden (62.3\%). Hasil uji chi square didapatkan nilai $p$ value 0.008 OR diperoleh nilai 10,5 (Cl 95\% 1,9-58,3), artinya persepsi positif perawat hambatan dari tindakan (perceived barrier to action) mendorong mereka 10,5 kali lebih besar untuk melakukan upaya pelayanan prima. 
Tabel 5. Pengaruh Persepsi Perawat Dengan Upaya Pelayanan Prima

\begin{tabular}{|c|c|c|c|c|}
\hline \multirow{2}{*}{ Variabel } & \multicolumn{2}{|c|}{ Analisis Bivariat } & \multicolumn{2}{|c|}{ Analisis Multivariat } \\
\hline & p.value & $\begin{array}{c}\operatorname{Exp}(B) \\
95 \% \text { C.l.for } \operatorname{EXP(B)}\end{array}$ & p.value & $\begin{array}{c}\operatorname{Exp}(B) \\
95 \% \text { C.I.for EXP(B) }\end{array}$ \\
\hline $\begin{array}{l}\text { Perceived } \\
\text { susceptibility }\end{array}$ & .021 & $\begin{array}{c}4.219 \\
(1.246-14.280)\end{array}$ & .010 & $\begin{array}{c}25.472 \\
(2.175-298.322)\end{array}$ \\
\hline Perceived severity & .001 & $\begin{array}{c}12.179 \\
(2.979-49.780)\end{array}$ & .201 & $\begin{array}{c}6.012 \\
(90.385-93.932)\end{array}$ \\
\hline $\begin{array}{l}\text { Perceived benefit of } \\
\text { action }\end{array}$ & .003 & $\begin{array}{c}13.200 \\
(2.403-72.500)\end{array}$ & .005 & $\begin{array}{c}46.512 \\
(3.201-675.802)\end{array}$ \\
\hline $\begin{array}{l}\text { Perceived barrier to } \\
\text { action }\end{array}$ & .007 & $\begin{array}{c}10.500 \\
(1.893-58.242) \\
\end{array}$ & .841 & $\begin{array}{c}1.396 \\
(0.054-36.344) \\
\end{array}$ \\
\hline
\end{tabular}

Berdasarkan tabel 5 tersebut di atas dapat dilihat bahwa seluruh vaiabel bebas pada Analisis Bivariat mempunyai batas signifikansi $p$-value $\leq 0.21$ yang berarti Ho ditolak dan $\mathrm{Ha}$ diterima, sehingga dapat disimpulkan bahwa ada pengaruh antara masing-masing variabel bebas dengan variabel terikat. Semua variabel mempunyai pengaruh terhadap upaya pelayanan prima dengan nilai $p$-value $<0.05$. Variabel perceived benefit of action merupakan variabel yang paling dominan mempengaruhi variabel upaya pelayanan prima dengan nilai $\operatorname{Exp}(B)=46,512$.

\section{PEMBAHASAN}

Persepsi kerentanan/kemungkinan terkena suatu penyakit (perceived susceptibility)

"Perceived susceptibility represents a person's ideation regarding the likelihood of getting a condition"; Kerentanan yang dirasakan mewakili persepsi seseorang mengenai kemungkinan mendapatkan suatu kondisi. Dengan kata lain persepsi perawat tentang kemungkinan terkena, terpapar, atau tertular suatu penyakit akan mempengaruhi pemikirannya untuk menghindari risiko tersebut baik untuk dirinya sendiri serta keluarga pasien atau pengunjung lainnya (Zhu, \& Owen, 2017). Persepsi perawat positif perawat terhadap kemungkinan tertular suatu penyakit dari pelanggan/pasien (perceived susceptibility), menimbulkan rasa tanggung jawab (responsibility) sebagai salah satu dimensi pelayanan prima mencakup kecepatan dan ketepatan dalam memberikan pelayanan serta keakuratan dalam memberikan informasi. Hal tersebut terlihat jelas dari hasil penelitian ini di mana mayoritas para perawat sangat setuju jika terdapat kebijakan-kebijakan seperti membatasi kunjungan keluarga pasien ke rumah sakit, melarang membawa anak dibawah umur berkunjung ke rumah sakit untuk melihat keluarganya yang sakit dan melarang keluarga pasien makan dilantai ruangan inap pasien. Ini membuktikan adanya rasa tanggung jawab yang tinggi dari para perawat agar diri keluarga pasien dapat terhindar kemungkinan tertular suatu penyakit dari klien/pasien.

\section{Persepsi terhadap Keparahan Penyakit (Perceived Severity)}

"Perceived severity represents the seriousness (medically, such asrisk of death, and socially, such as stigmatization) associated with that diseas"; persepsi keparahan yang dirasakan mewakili keseriusan (secara medis, seperti risiko kematian, dan secara sosial, seperti stigmatisasi) yang terkait dengan penyakit tersebut. Pendapat ini menjelaskan bahwa persepsi positif perawat terhadap keparahan atau keseriusan penyakit yang sedang diderita klien/pasien berdasarkan keyakinannya dengan melihat penyakit- penyakit dari tingkat keparahan atau keseriusan penyakit tersebut didasarkan dari informasi-informasi medis atau pengetahuan pribadinya akan mempertimbangkan seberapa parah konsekuensi yang akan terjadi tidak diberi penanganan yang lebih baik. Semakin perawat percaya bahwa suatu konsekuensi yang terjadi akan semakin memburuk, maka mereka akan merasakan hal tersebut 
sebagai dorongan dan mengambil tindakan preventif (Zhu, \& Owen, 2017).

Persepsi perawat yang positif terhadap keparahan penyakit klien/pasien akan melahirkan sikap empati sebagai salah satu dimensi dari pelayanan prima, yaitu kemampuan untuk memahami dan memperhatikan kondisi psikologis pasien, yang dalam hal ini diperlukan upaya untuk memberikan kenyamanan kepada pasien. Pelayanan yang prima akan sangat memperhatikan individu sebagai pribadi yang unik dan menarik. Rasa empati akan menimbulkan sikap perawat yang menyenangkan, memiliki ketrampilan dan kemampuan serta mempunyai pertimbangan-pertimbangan yang tidak hanya pada perawatan fisik tetapi juga pada kepribadian pasien. Selain itu pelayanan prima tersebut akan diwujudkan dengan memberikan pelayanan kepada pasien berdasarkan standar kualitas untuk memenuhi kebutuhan dan keinginan pasien sehingga pasien dapat memperoleh kepuasan yang akhirnya dapat meningkatkan kepercayaan pasien kepada rumah sakit.

\section{Persepsi terhadap Manfaat dari Tindakan (Perceived Benefit of Action)}

"Perceived benefits are the attitudes about how much there is to gain by engagingin a particular preventive action; Persepsi terhadap adalah sikap tentang seberapa banyak yang dapat diperoleh dengan melibatkan tindakan pencegahan tertentu. Pendapat ini menjelaskan bahwa persepsi terhadap manfaat dari suatu tindakan yang dilakukan perawat adalah pandangan pribadi perawat mengenai nilai atau kegunaan dari perilaku-perilaku atau tindakan-tindakan yang dilakukan dalam tujuan untuk mengurangi risiko mengembangkan penyakit yang diderita pasien. Persepsi positif perawat tentang manfaat tindakan ini tidak melihat sisi negatif dari suatu penyakit tetapi malah melihat sisi positif atau keuntungan ketika ia dapat memberikan tindakan-tindakan yang tepat untuk mempercepat penyembuhan penyakit pada klien/pasien (Zhu \& Owen (2017).

Persepsi perawat tentang tentang manfaat dari tindakan (perceived benefit of action) berhubungan dengan kepuasan pasien terhadap upaya pelayanan prima menunjukkan adanya sikap kepekaan (responsiveness) terhadap kebutuhan pasien yang diiringi dengan tindakan yang tepat sesuai dengan kebutuhan tersebut. Sebagai salah satu dimensi pelayanan prima, sikap kepekaan (responsiveness) terhadap kebutuhan pasien merupajan sesuatu sesuatu yang sangat penting, karena ketika perawat berhadapan dengan pasien dan keluarga pasien, akan menghadapi kecemasan, keluhan, tuntutan dan mekanisme pertahanan diri pasien yang muncul karena kondisi fisiknya yang lemah dan dalam kondisi sakit. Dalam situasi yang demikian perawat diharapkan dan dituntut untuk dapat mengatasi masalah dengan cara memahami alur pikiran dan perasaan pasien dengan segala manifestasi psikologis yang muncul akibat penyakit yang dideritanya dan mengambil tindakan-tindakan yang tepat untuk mengatasi keluhan-keluhan klien/pasien maupun keluarga klien/pasien (Vogus, \& McClelland, 2016).

\section{Persepsi hambatan dari tindakan ( perceived barrier to action)}

Perceived barrier to action represent feelings associated with the potential negative aspects of a particular health behavior; persepsi hambatan dari tindakan mewakili perasaan yang terkait dengan aspek negatif potensial dari perilaku kesehatan tertentu. Pendapat ini menjelaskan bahwa persepsi positif perawat terhadap hambatan dari tindakan atau upaya pelayanan yang dilakukannya akan membentuk sikap untuk melakukan evaluasi diri dari setiap tindakan atau pelayanan yang diberikan, apakah tindakan tersebut tepat untuk dilakukan atau tidak. Persepsi ini juga akan membentuk sikap untuk mengatasi atau meminimalisir semua hambatan agar pelayanan dapat diberikan secara lebih optimal (Zhu \& Owen (2017).

Temuan hasil penelitian ini menunjukkan persepsi perawat yang menganggap perlu adanya kepastian pelayanan (assurance), yaitu bentuk layanan langsung dalam membantu pasien, yang didukung dengan pengetahuan dan keterampilan. Persepsi positif terhadap kepastian pelayanan akan mendorong terjadinya peningkatan kemampuan perawat atas pengetahuan terhadap produk/jasa secara tepat, kualitas keramahtamahan, perhatian dan kesopanan dalam memberikan pelayanan, ketrampilan dalam memberikan informasi, kemampuan di dalam memberikan keamanan di dalam memanfaatkan jasa yang ditawarkan, dan kemampuan di dalam menanamkan kepercayaan klien/pasien terhadap rumah sakit. Hal tersebut tentunya akan mempengaruhi penilaian kepuasan klien/pasien terhadap mutu pelayanan rumah sakit. 


\section{Upaya Pelayanan Prima}

"Excellent service is an act of service that will motivate others to talk about it positively. Excellent service creates a desire in the customer to repeat the experience"; pelayanan prima adalah tindakan layanan yang akan memotivasi orang lain untuk membicarakannya secara positif. Layanan prima menciptakan keinginan pelanggan untuk mengulangi pengalaman itu. Definisi ini memberikan gambaran bahwa Pelayanan Prima merupakan pemberian layanan terbaik yang diberikan oleh pegawai pada suatu instansi terhadap klien atau pelanggannya. Terkait dengan pelayanan prima di rumah sakit, dapat disimpulkan bahwa pelayanan prima adalah pelayanan rumah sakit untuk memenuhi/bahkan melampaui harapan pengguna jasa rumah sakit (Crouch, 2013).

Suatu organisasi modern dan maju, bentuk kualitas kondisi fisik menjadi pertimbangan dalam upaya memberikan pelayanan prima kepada pelanggan. Kualitas pelayanan berupa kondisi fisik merupakan bentuk kualitas pelayanan nyata yang memberikan adanya apresiasi dan membentuk persepsi positif bagi setiap individu yang dilayani. Kemampuan rumah sakit dalam menunjukan eksistensinya para pelanggan baik dalam bentuk fisik bangunan, sarana dan prasarana maupun tampilan para pegawai rumah sakit adalah bentuk aktualisasi nyata secara fisik yang dapat dirasakan para pelanggan yang menginginkan pelayanan, sehingga puas atas pelayanan yang dirasakan.

Pelayanan yang prima juga memerlukan bentuk pelayanan yang handal, artinya dalam memberikan pelayanan, setiap pegawai diharapkan memiliki kemampuan dalam pengetahuan, keahlian, kemandirian, penguasaan dan profesionalisme kerja yang tinggi, sehingga aktivitas kerja yang dikerjakan menghasilkan bentuk pelayanan yang memuaskan, tanpa ada keluhan dan kesan yang berlebihan atas pelayanan yang diterima oleh pelanggan/ klien. Kemampuan rumah sakit untuk memberikan pelayanan sesuai dengan yang dijanjikan secara akurat dan terpercaya dan sesuai dengan harapan dan tuntutan pelanggan / klien terhadap kehandalan perawat dalam memberikan pelayanan yang cepat,tepat, mudah dan lancar. Inti dari bentuk kehandalan pelayanan adalah setiap perawat memiliki kemampuan yang handal, mengetahui mengenai seluk belum prosedur kerja, mekanisme kerja, memperbaiki berbagai kekurangan atau penyimpangan yang tidak sesuai dengan prosedur kerja dan mampu menunjukkan, mengarahkan dan memberikan arahan yang benar kepada setiap bentuk pelayanan yang belum dimengerti oleh pelanggan/klien, sehingga memberi dampak positif atas pelayanan tersebut. Selain daripada itu, setiap orang yang mendapat pelayanan sangat membutuhkan penjelasan atas pelayanan yang diberikan agar pelayanan tersebut jelas dan dimengerti. Untuk mewujudkan dan merealisasikan hal tersebut, maka kualitas layanan daya tanggap mempunyai peranan penting atas pemenuhan berbagal penjelasan dalam kegiatan pelayanan kepada klien / pasien. Apabila pelayanan daya tanggap diberikan dengan baik atas penjelasan yang bijaksana, penjelasan yang mendetail, penjelasan yang membina, penjelasan yang mengarahkan dan yang bersifat membujuk, apabila hal tersebut secara jelas dimengerti oleh klien / pasien, maka secara langsung pelayanan dapat dianggap berhasil dan menjadi suatu bentuk kualitas pelayanan yang prima.

Setiap bentuk pelayanan memerlukan adanya kepastian atas pelayanan yang diberikan. Bentuk kepastian dari suatu pelayanan di rumah sakit sangat ditentukan oleh jaminan dari pegawai yang memberikan pelayanan, sehingga orang yang klien I pasien merasa puas dan yakin bahwa segala bentuk urusan pelayanan yang dilakukan atas tuntas dan selesai sesuai dengan kecepatan, ketepatan, kemudahan, kelancaran dan kualitas layanan yang diberikan. Selain itu Memberikan pelayanan dengan empati sangat penting dalam memberikan suatu kualitas pelayanan yang prima kepada klien / pasien. Empati tersebut ditunjukkan dengan kemampuan memahami klien / pasien yang dilayani dengan penuh perhatian, keseriusan, simpatik, pengertian dan adanya keterlibatan dalam berbagai permasalahan yang dihadapi klien/pasien. Pada aspek empati, mayoritas responden menyatakan perawat sopan terhadap pasien, perawat yang perhatian kepada pasien, perawat yang memahami kebutuhan pasien, perawat mengerti kesulitan pasien, perawat tidak menyepelekan pasien, serta perawat yang tidak membedakan antara pasien satu dengan pasien yang lain.

\section{Pengaruh Persepsi perawat tentang perceived susceptibility, perceived severity, perceived benefits dan perceived barriers terhadap Upaya Pelayanan Prima}

Mutu pelayanan kesehatan tidak lepas upaya pelayana prima yang diberikan kepada pasien,

\section{Eri Murni Asih", Dessy Hermawan², Teguh Pribadi ${ }^{2}$}

'RSUD dr.H.Bob Bazar,SKM Kabupaten Lampung Selatan. *Email Murni.gawoh@gmail.com

${ }^{2}$ Program Studi llmu Keperawatan Universitas Malahayati. 
dimana mutu yang baik dikaitkan dengan kesembuhan dari penyakit, peningkatan derajat kesehatan atau kesegaran, kecepatan pelayanan, lingkungan perawatan yang menyenangkan, keramahan petugas, kemudahan prosedur, kelengkapan alat, obat-obatan dan biaya yang terjangkau. Setelah mendapatkan pelayanan, klien/ pasien akan memberikan reaksi terhadap hasil pelayanan yang diberikan, apabila pelayanan yang diberikan sesuai dengan harapan/keinginan klien/ pasien maka akan menimbulkan kepuasan pelanggan, namun sebaliknya apabila pelayanan yang diberikan tidak sesuai dengan harapan/keinginan pelanggan maka akan menimbulkan ketidakpuasan pelanggan atau keluhan pelanggan. Ketidakpuasan yang diperoleh pada tahap awal pelayanan menimbulkan persepsi berupa kualitas pelayanan yang buruk untuk tahap pelayanan selanjutnya, sehingga pelanggan merasa tidak puas dengan pelayanan secara keseluruhan.

Hasil penelitian ini menunjukkan bahwa upaya pelayanan prima terkait lima dimensi mutu pelayanan asuhan keperawatan yang meliputi penampilan fisik perawat, kehandalan perawat, daya tanggap perawat, jaminan perawat, dan empati perawat dipengaruhi oleh persepsi perawat Persepsi perawat terhadap kerentanan/kemungkinan terkena suatu penyakit (perceived susceptibility), persepsi perawat terhadap kerentanan/kemungkinan terkena suatu penyakit (perceived susceptibility), persepsi perawat terhadap keparahan penyakit (perceived severity), persepsi perawat terhadap manfaat dari tindakan (perceived benefit of action), dan persepsi perawat terhadap hambatan dari tindakan (perceived barrier to action). Untuk itu dalam rangka upaya pelayanan prima diperlukan adanya upaya-upaya untuk memperhatikan variabelvariabel yang yang dapat mempengaruhi persepsi perawat terhadap upaya pelayanan prima sebagaimana ditunjukkan oleh hasil penelitian ini sehingga dapat memberikan dampak yang signifikan terhadap peningkatan upaya pelayana prima, terutama yang berkaitan dengan lima dimensi mutu pelayanan yaitu penampilan fisik, kehandalan, daya tanggap, jaminan, dan empati.

\section{SIMPULAN}

Terdapat hubungan antara persepsi perawat disemua variabel dengan upaya pelayanan prima di Rumah Sakit Umum Dr. H. Bob Bazar, SKM
Lampung Selatan ( $p$-value $<0,05$ ). Variabel perceived benefit of action merupakan variabel yang paling dominan mempengaruhi variabel upaya pelayanan prima dengan nilai $\operatorname{Exp}(B)=$ 46,512 .

\section{SARAN}

Diperlukan adanya upaya-upaya pihak manajemen rumah sakit mendorong persepsi positif perawat tentang kemungkinan terkena suatu penyakit dengan menerapkan kebijakan-kebijakan yang meningkatkan rasa aman perawat saat menjalankan tugas keperawatan. Upaya pengembangan standar operasional prosedur yang jelas, meningkatkan ketersediaan sarana dan prasarana yang memadai.

Diperlukannya upaya-upaya untuk meminimalisir setiap hambatan dan upaya-upaya untuk meningkatkan persepsi perawat berkaitan dengan persepsi perawat terhadap manfaat dari tindakan (perceived benefit of action) ke arah lebih positif karena persepsi perawat variabel ini berpengaruh paling dominan mempengaruhi variabel upaya pelayanan prima.

Terkait dengan bidang promosi kesehatan, diperlukan upaya-upaya untuk mengatasi, memelihara, meningkatkan serta melindungi kesehatan baik para karyawan maupun pasien dan masyarakat secara umumnya melalui promosi kesehatan di tempat kerja untuk menciptakan proses kesehatan yang berkelanjutan. Melalui upaya ini diharapkan akan meningkatkan persepsi perawat menjadi lebih positif pada ujungnya dapat berdampak pada upaya peningkatan pelayanan prima di Rumah Sakit Umum Dr. H. Bob Bazar, SKM Lampung Selatan.

\section{DAFTAR PUSTAKA}

Agustin, D. I. (2017). Hubungan penerapan pelayanan prima (service excellent) terhadap kepuasan pasien rawat jalan.

Bakri, M. H. (2017). Manajemen Keperawatan, Konsep dan Aplikasi dalam Praktik Keperawatan Profesional. Yogyakarta: Katalok Dalam Terbitan.

Crouch, C. D. (2013). The Excellent Experience: $A$ Blueprint for Organizational, Team, and Individual Success. iUniverse.

Eri Murni Asih", Dessy Hermawan², Teguh Pribadi ${ }^{2}$

'RSUD dr.H.Bob Bazar,SKM Kabupaten Lampung Selatan. *Email Murni.gawoh@gmail.com

${ }^{2}$ Program Studi llmu Keperawatan Universitas Malahayati. 
Djasri, H. (2016). Tingkatkan Mutu Pelayanan Kesehatan Indonesia Reportase dari Konferensi Internasional ISQua di Tokyo 16-19 Oktober 2016. Di akses dari: https://www.mutupelayanankesehatan.net/11networking/2335-reportase-dari-konfrensiinternasional-isqua-di-tokyo

Hadjam, M. N. R. (2015). Efektivitas pelayanan prima sebagai upaya meningkatkan pelayanan di Rumah Sakit (Perspektif Psikologi). Jurnal Psikologi, 28(2), 105-115.

Hayden, J. (2017). Introduction to health behavior theory. Jones \& Bartlett Learning.

Husna, C. (2014). Upaya Pencegahan Kekambuhan Asma Bronchial Ditinjau Dari Teori Health Belief Model Di Rsudza Banda Aceh. Idea Nursing Journal, 5(3), 75-89.

Kementerian Kesehatan Republik Indonesia. (2009). UU No. 36 tahun 2009 tentang Kesehatan. Diakses dari https://infeksiemerging.kemkes.go.id/download/U U_36_2009_Kesehatan.pdf

Kementerian Kesehatan Republik Indonesia. (2019). Peraturan Menteri Kesehatan Republik Indonesia nomor 33 tahun 2019 tentang panduan perilaku interaksi pelayanan publik di lingkungan kementerian kesehatan http://hukor.kemkes.go.id/uploads/produk_hukum/ PMK No 33 Th $2019 \mathrm{ttg}$ Panduan Perilaku I nteraksi Pelayanan Publik di Lingkungan KEM ENKES.pdf

Kuntoro, W., \& Istiono, W. (2017). Kepuasan pasien terhadap kualitas pelayanan di tempat pendaftaran pasien rawat jalan Puskesmas Kretek Bantul Yogyakarta. Jurnal Kesehatan Vokasional, 2(1), 140-147.

Kurniawan, R., Ibrahim, K., \& Suwignyo, P. (2011). Prediktor Kepatuhan Perawat dalam Penerapan Kewaspadaan Standar di IGD dan ICU. Majalah Keperawatan Unpad, 12(2).

Lembaran Negara Republik Indonesia. (2014). Undang-Undang Republik Indonesia Nomor 38 tahun 2014 tentang keperawatan. Diakses dari: https://www.persi.or.id//images/regulasi/uu/uu3820 14.pdf
Merita, A. (2016). Health Belief Model pada Kepatuhan Hand Hygiene di Bangsal Berisiko Tinggi Healthcare Acquired Infections (HA/s) (Studi Kasus Pada Rumah Sakit X). Magister Manajemen Rumah Sakit Univeristas Muhammadiyah Yogyakarta.

Nursalam, M. (2014). Manajemen Keperawatan. Jakarta: Salemba Medika.

Nurseha, D. (2017). Development of Nosocomial Infection Prevention Measured by Nurses at Hospital Based on Health Belief Model. Jurnal Ners, 8(1), 64-71.

Purwoastuti, E., \& Walyani, E. S. (2015). Mutu pelayanan kesehatan dan kebidanan. Yogyakarta: Pustaka Baru Press. Analisis Faktor Yang Mempengaruhi Tingkat Kecemasan Wanita (Zulfah NN \& Sri Hadi S.), 156.

Setiyaningsih, R., Tamtomo, D., \& Suryani, N. (2016). Health belief model: determinants of hypertension prevention behavior in adults at community health center, sukoharjo, central java. Journal of Health Promotion and Behavior, 1(3), 160-170.

Stanhope, M., Faan, R. D., Lancaster, J., \& Faan, R. P. (2018). Public Health Nursing E-Book: Population-Centered Health Care in the Community. Elsevier Health Sciences.

Subaris, H. (2016). Promosi Kesehatan, Pemberdayaan Masyarakat, dan Modal Sosial. Yogyakarta: Nuha Medika.

Vogus, T. J., \& McClelland, L. E. (2016). When the customer is the patient: Lessons from healthcare research on patient satisfaction and service quality ratings. Human Resource Management Review, 26(1), 37-49.

Zhu, W., \& Owen, N. (2017). Sedentary behavior and health: Concepts, assessments, and interventions. Human Kinetics.

Zrymiak, D. (2017). Achieving Customer Experience Excellence through a Quality Management System. The Quality Management Journal, 24(1), 46. 